\title{
SF-puheenvuoro matkailun mahdollisista maailmoista
}

Tarja Salmela, Lapin yliopisto, Matkailualan tutkimus- ja koulutusinstituutti (MTI)

Onko post-traumaattinen maailma yhtä kuin post-antroposentrinen - ihmiskeskeisen jälkeinen? Tarjoaako covid-19-viruspandemien jälkeinen post-traumaattinen maailma mahdollisuuden rakentaa ihmisestä laajentuvaa käsitystä matkailusta? Millaista on matkailu, jota ei ole kehitetty ihmisen hedonististen tarpeiden täyttämistä varten? Kysymys on monimutkainen ja osittain myös absurdi. Maapalloamme koskettava ympäristöllinen muutos johtaa kuitenkin väistämättä globaalin poliittisen, taloudellisen ja sosiaalisen järjestyksen uudelleenmuotoilemiseen (Klein, 2014). Kapitalistiseen järjestelmään kytkeytyvä matkailun toimiala on myös osa tätä uudelleenmuotoilua (Huijbens \& Gren, 2016).

Matkailua ei kuitenkaan voida ajatella pelkästään kapitalistisen järjestelmän osana. Matkailun ymmärtäminen laajempana ilmiönä ja käytäntöjen kokoelmana on välttämätöntä pohtiessamme matkailun vaihtoehtoisia tulevaisuuksia. Jos matkailu on konteksti, jossa ihmisen ja luonnon välisiä suhteita muotoillaan ja tehdään merkityksellisiksi (Grimwood ym., 2018), ovat matkailun mahdolliset maailmat lähtökohtaisesti ihmisen ylittäviä (more-than-human) maailmoja. Miten lähestyä näitä maailmoja?

Tämä puheenvuoro on yksi yritys tällaiseen lähestymiseen. Se syleilee absurdiutta ja edustaa spekulatiivista fabulaatiota ja feminismiä (SF)'. Tämä puheenvuoro on siis SF-puheenvuoro. SF on yhtäaikaisesti tieteisfiktiota ja faktaa, yhtä paljon tarinoita kuin "tosiasioita". SF on sympoieettista - kollektiivista, mutkikasta, rajoittamatonta - "teoriaa mudassa, sekasotkuna" (Haraway, 2016, s. 31). Se on haaste matkailututkijoille ja -toimijoille. Samalla se on kollektiivinen kutsu jollekin, mikä on "vielä mahdollista", kollektiivinen kutsu "pysyä pulman kanssa" (Haraway, 2016).

1 SF toimii tässä puheenvuorossa lyhenteenä Harawayn (2016) ehdottamalle käsitteelle Speculative Fabulation. SF on myös lyhenne muille spekulatiiviseen fabulaatioon kytkeytyville käsitteille. Haraway kuvaa sitä seuraavasti: "An ubiquitous figure in this book is sf: science fiction, speculative fabulation, string figures, speculative feminism, science fact, so far" (Haraway, 2016, s. 3). Tässä puheenvuorossa painotan SF:n spekulatiivisen fabulaation ulottuvuutta. 


\section{Huutomerkillä varustettu...}

...pulma on tässä hetkessä covid-19. Vaikka viruspandemian vaikutukset ovat todellisia ja vaikutuksiltaan valtavia, ne eivät ole ainoita haasteita, joiden kanssa meidän tulee tällä hetkellä ja tulevaisuudessa elää. Myös ilmaston lämpeneminen, luonnon monimuotoisuuden radikaali köyhtyminen ja useiden asuinympäristöjen muuttuminen turistikohteiksi paikallisten yhteisöjen kustannuksella ovat massiivisia ongelmia, joiden kanssa elämistä emme voi ohittaa tai vähentää niihin sitoutumista. Nämä ongelmat eivät myöskään häviä, vaikka oppisimmekin lopulta elämään koronaviruksen kanssa.

Covid-19-pandemian antamien oppituntien myötä voinemme kuitenkin todeta jotain matkailun tulevaisuudesta. Vaikka tiedämme tulevaisuudesta verrattain vähän, varmaa lienee se, että tulevaisuuden postpandeminen matkailu ei voi jatkua sellaisena kuin sen tunnemme. $\mathrm{Pu}$ hun tässä matkailun traditionaalisesta luonteesta hedonististen tarpeidemme tyydyttäjänä ja kapitalistisen ansaintalogiikan mukaisesti toteutettuna toimintana, joka pohjautuu vahvasti lentomatkustamiseen. ${ }^{2}$ Matkailu on ollut jatkuvan kritiikin kohteena muun muassa siksi, että toimialalta puuttuu pitkäjänteinen visio. Matkailun tiedetään olevan niin ilmastonmuutokseen kuin globaaleihin terveyden hätätiloihin liittyvä riskitekijä (Jamal \& Budke, 2020). Matkailun nimeäminen pelkäksi riskitekijäksi lienee kuitenkin sen vaikutusten vähättelyä. Matkailun globaali jalanjälki on huomattava, ja se todennäköisesti vain kasvaa tulevaisuudessa (ks. Eijgelaar ym., 2016). Matkailulla ja matkailijoilla voidaankin nähdä olevan todellista geopoliittista voimaa. ${ }^{3}$ Gren ja Hujbens (2016) toteavat, että matkailu ja matkailijat tulee nähdä alati liikkeessä olevan ihmiskunnan kontekstissa, "toisin sanoen kokonaisena lajina, joka kasvavalla geo-toimijuudella kykenee muuttamaan planeettaa matkustamalla" (s. 5, vapaa suomennos).

Mutta onko matkailijan geopoliittinen voima yksioikoisesti paha tai kestämätön asia? Matkailun demonisointi ja toisaalta demonisointia vastustava liikehdintä matkailutoimialan sisällä ovat olleet vahvasti esillä viruspandemian runtelemassa maailmassa, myös Suomessa ja Suomen Lapissa. ${ }^{4}$ On puhuttu matkailutoimialan työvoimapoliittisesta ja aluetaloudellisesta merkityksestä sekä matkailusta ihmisten hyvinvoinnin lähteenä - eräänlaisena arjen pakokeinona. Mutta onko kestävää paeta arkea matkailun avulla? Kysymys herättää lukuisia jatkokysymyksiä, ja aiheesta on vaikea keskustella julkisesti ilman tuomituksi tulemista. Kaiken kaikkiaan matkailun kritisointi on arka aihe.

Matkailun murrosta heijastavat yhteiskunnalliset, sähköistyneet keskustelut motivoivat kuitenkin tarkastelemaan matkailun yleistävän "arvottamisen" sijaan matkailu(liiketoiminna)n vakiintuneita, ideologisiakin motiiveja ja päämääriä. Niitä ovat muun muassa kasvutavoitteisuus

2 Matkailuliikenne ja erityisesti lentomatkustaminen on tunnetusti suurin matkailun päästöjen absoluuttisen kasvun aiheuttaja (ks. mm. Eijgelaar ym., 2016, s. 25).

3 Geopoliittisella viittaan tässä geososiaalisuuden tunnistavaan ymmärrykseen geopoliittisuudesta: sen sijaan, että "geoksella" - maalla - olisi merkitystä vain politiikan raaka-aineiden lähteenä, geososiaalisessa lähestymistavassa "geos" nähdään myös itsessään sosiaalisena (ks. Palsson \& Swanson, 2016, s. 163-164). Puheenvuorossani matkailun ja matkailijoiden geopoliittinen voima näyttäytyy suhteisena "geoksen" sosiaalisuuteen: matkailijoiden geopoliittinen voima syntyy huomattavasta vaikutuksesta "geokseen" tässä suhteisuudessa, tekemättä kuitenkaan "geoksesta" passiivista taustaa, tapahtumakenttää tai resurssia ihmisen toimille.

4 Tästä viestivät muun muassa Helsingin matkailuseminaarin 2020 ja Lapin Matkailuparlamentin 2020 sisällöt. 
sekä vauraiden yhteiskuntien ihmisväestölle tyypillinen ehtymätön tarve saavuttaa hetkellisiä elämyksellisiä kokemuksia (Huijbens, 2020). Tätä tarvetta tyydytetään erityisesti kauaksi suuntautuvalla lentomatkustamisella, jonka ennustetaan entistetään kasvavan, jos kulutuskäyttäytymisen muutosta ei tueta poliittisilla, lainsäädännöllisiä muutoksilla (ks. Eijgelaar ym., 2016, s. 27-29). Toisaalta Suomessa myös suosiotaan kasvattanut luontomatkailu on aiheuttanut mittasuhteiltaan uudenlaista kuormitusta muun muassa Lapin luonnolle (ks. mm. Bjurström \& Virtanen, 2019; Mehtonen \& Heikinmatti, 2019). YLE kysyi osuvasti erityislähetyksessään: "Mitkä ovat Lapin matkailun kasvun rajat?" (YLE, 2019).

Edellä tarkastellut kysymykset puhuttavat matkailututkijoita ympäri maailmaa. TRINET (Tourism Research Information Network) -keskustelufoorumille on kertynyt paljon aloitteita viruspandemian aikaisen ja sen jälkeisen matkailun kriittiseen tarkasteluun. Matkailututkijat ottavat kantaa siihen, mikä on tärkeää ja merkityksellistä. Tutkijat ovat myös pohtineet, miten covid-19 voi opettaa meitä vastaamaan ilmastonmuutokseen ja sen seurauksiin tavalla, joka mahdollistaa matkailun kukoistamisen postpandemisessa maailmassa (Prideaux ym., 2020). Keskusteluissa on tuotu esille, että matkailu voi tarjota kenties välttämättömän, globaalin näkökulman elämään planeetallamme. BBC:n journalisti Chloe Bergen (2020) sanoin: "[näkökulmaa], jota tarvitsemme pystyäksemme huolehtimaan (care about) kotimme tulevaisuudesta täällä maapallolla" (vapaa suomennos). Jos matkailu sellaisena kuin sen tunnemme loppuisi, menettäisimmekö tämän huolenpidon kyvyn? Miten Bergen ehdottama huolenpidon näkökulma voidaan yhdistää tieteellisesti tunnistettuun välttämättömyyteen vähentää lentoliikennettä ja matkaetäisyyksiä, jotta pystymme palauttamaan "matkailun takaisin ilmastollisesti turvalliselle toiminta-alueelle" (Eijgelaar ym., 2016, s. 29)?

\section{Vastuullisuudesta vastuunoton kykyyn}

Feministiset (uus)materialistiset teoriat ehdottavat vastuullisuuden aktiivista ja affektiivista, hoivaan ja toimintaan perustuvaa luonnehdintaa - vastuullisuutta, joka ulottuu kiperiin ja vaikeisiin tilanteisiin. Vastuunoton kyky linkittyy intiimisti hoivaan ja huolenpitoon (ks. mm. Puig de la Bellacasa, 2017). Siinä hoiva ei rakennu moraaliselle velvoitteelle tai säännöstölle, vaan siihen sitoudutaan ilman pakkoa (Koskinen ym., 2018; Puig de la Bellacasa, 2017 s. 170). Antroposeenin ajassa vastuunottoon kykeneminen on aktiivista toimintaa suhteessa niihin mittaviin ongelmiin, joiden syntyyn ihmislajimme on ollut vaikuttamassa tai joiden synnyn se on aiheuttanut. Vastuunoton kyky hoivan ja huolenpidon muotona on jatkuvaa kanssaelämistä pulman kanssa (Haraway, 2016) - sen mittasuhteiden tunnistamista ja yhteisen hyvän edistämistä.

SF:n valossa postpandeminen matkailu voi hyvinkin olla askel kohti uutta vastuullisuutta. Postpandeminen matkailu voi olla "ihmiskeskeisen jälkeistä" matkailua. Vastuullinen matkailu käsitteenä on pahimmillaan pölyttynyt kategorinen lokero, "normi", johon kenties kaikkien matkailutoimijoiden pitäisi pyrkiä mutta jonka mittaristo ja sisältö ovat yhtä tulkinnanvaraisia kuin kansakuntien keskimääräisen onnellisuuden mittarit. Normatiivisuuteen perustuvan vastuun

5 Vastuunoton kyky on yksi mahdollinen suomennos response-ability-käsitteelle (englanninkielisestä käsitteestä ks. Haraway, 2008; suomennoksista ks. Kortekallio ym., tulossa). 
sijaan tarvitsemme myös uudenlaisia tekoja, emme vain uusia käsitteitä. Hoivan, huolenpidon ja välittämisen kysymykset ovat kompleksisia. SF:n hengessä meidän on kuitenkin sitouduttava niihin pohtiessamme matkailun tulevaisuutta. Kenestä huolehdimme? Kenen kodin tulevaisuudesta pidämme huolta? Keneen luomme hoivaavia suhteita? Miten määrittelemme sen, kuka on hoivan arvoinen? Kuka sen määrittelee?

Sitoutuminen on vastuunottoa. Vastuunottamisen kyky on eettinen impulssi, jopa vaade, elämämme suhteisuudelle. Se on vastuunottoa hoivaamisen ja hoivanaiheiden "valintojen" seurauksista (Fisher \& Tronto, 1990, s. 42; Kinnunen, 2017; Koskinen ym. 2018, s. 27). Vastuullisuuden ja vastaamisen harjoittelu (Alaruona, 2018, s. 45) viittaa omistautumiseen kärsivälliselle, affektiiviselle työlle, joka avaa meidät suhteiselle hoivalle ja ihmisen ylittävälle elämälle. Ihmisen ylittävä elämä on posthumanistisen ja materiaalisrelationaalisen filosofian mukaista olemassa olemisemme todellisuutta. Siinä ihminen asettuu ontologisesti osaksi laajempaa olemassaolon verkostoa, ollen osa maailmaa yhdessä muiden kanssa. "Enemmän-kuin-inhimillinen" ontologia ylittää eronteot inhimillisen ja ei-inhimillisen välillä ja kumoaa illuusion ihmisen erityisyydestä maailmassa (ks. mm. Barad, 2003, 2007; Haraway, 2008, 2016; Tsing, 2015). Enemmän-kuininhimillinen ontologia on luopumista mekanistisesta maailmankatsomuksesta, joka on asettanut ihmisen maailman navaksi ja täten "auttanut antroposentrismiä - kirjaimellisesti, ihmiskeskeisyyttä - juurtumaan kaikille modernin länsimaisen yhteiskunnan osa-alueille" (Vetlesen, 2019, s. 1, vapaa suomennos).

Ihmisen aseman ja paikan uudelleenarviointi planetaarisessa kokonaisuudessa ei riipu tieteenalasta, paradigmasta tai "käänteestä". Tarvitsemme "itsestäänselvyyksiä" problematisoivia väliintuloja yhteiskuntamme kaikilla osa-alueilla. Ihmisen erityisyyden kumoamista ei kuitenkaan ole nähtävissä matkailualan vallitsevissa todellisuuksissa. Matkailualan kritiikki rakentuu tällä hetkellä sekä matkailun lukuisten taloudellista voittoa tavoittelevien toimijoiden (kuten lentoyhtiöt, matkanjärjestäjät ja kohdemaat sekä niiden markkinointitoimenpiteet) toiminnan oikeutuksen kriittiselle tarkastelulle että kuluttajien moralisoimiselle. Moralisointi kytkeytyy puolestaan etiikkaan ja eettisiin oletuksiin.

Sosiaalisen ja kulttuurisen teorian professori, STS-teoreetikko ${ }^{6}$ Gay Hawkins (2018) puhuu tavoista ymmärtää etiikka käyttäen esimerkkinä muovia ja sen hävittämistä (dispose-ability). Hawkinsin huomiot muovista ja sen hävittämisestä tarjoavat oivallisia näkökulmia post-antroposentrisen matkailun pohdintaan. Hawkinsille etiikan ymmärtäminen ihmiskeskeisesti on ongelmallista sen rakentuessa "vastuuntuntoon" ja "moraaliseen oikeassa olemiseen". Tässä ihmiskeskeisessä etiikassa ei ymmärretä laajemmin muovin kietoutumista elämäämme eikä sitä, kuinka "muovi on mukana muovaamassa eettistä toimintaa" sen sijaan, että se olisi vain instrumentaalinen, passiivinen objekti ihmisen hyveelliselle huomiolle. (Hawkins, 2018, s. 19.)

Kuten muovin kanssa eläminen myös post-antroposentrinen matkailu edellyttää ihmiskeskeisestä etiikasta irtautumista. On ymmärrettävä, että "luonto" ja "planeettamme" eivät ole vain objekteja ihmisen hyveelliselle huomiolle; "ympäristö" ei ole vain taustakuva eikä planeettamme Maa jonkinlainen "ulkopuolinen, ylimääräinen ulottuvuus" antroposentrisissä ambitioissamme (Huijbens ym., 2016, s. 48). Mutta miten matkailun ja luonnon ei-inhimillisten toimijoiden

6 STS = Science and Technology Studies. 
välisistä suhteista voisi tulla oikeudenmukaisempia? Mitä mahdollisuuksia tai haasteita matkailu asettaa pyrkimyksillemme eettisempään suhteeseen ihmisen ylittävän maailman kanssa (Grimwood ym., 2018, s. 2)?

Aiemmin mainitsemani vastuullisuuden pölyttynyt kategorinen lokero johtaa usein tilanteeseen, jossa koemme tekevämme "oikein" valitsemalla vastuullisen matkanjärjestäjän tai matkakohteen. Rakentuuko vastuullisen matkanjärjestäjän valinta juuri moraaliselle oikeassa-olemiselle - ihmiskeskeisen normatiivisen "oikein tekemisen vastuuntunnolle"? Onko jatkuvasti lisääntyvä lentomatkustaminen, planeettamme hätätilasta viestivistä mittavista tieteellisistä todisteista huolimatta, ehkä seurausta ihmiskeskeisen etiikkakäsityksen (tuomitusta) epäonnistumisesta?

Jotta emme hautautuisi kiperien kysymysten alle, lähestyn seuraavaksi spekulaatiota ja vaihtoehtoisia tarinoita. Kerron tarinan post-antroposentrisen ajan matkailusta Suomen Lapissa, kuvitteellisessa Pirpolan kylässä.

\section{Kun matkailusta tulikin kyläilyä}

Lapsen pulleat sormet ovat kostean mullan peittämät, lapsi on keskittynyt ja utelias ja mullassa asustavat kastemadot ottavat selkoa uudesta tuttavuudesta. Isovanhempien kahvi höyryää kahvikupeissa, kun linnut kilvoittelevat pihlajanmarjoja pullollaan olevilla puun oksilla. Linnut ja isovanhemmat ovat tietämättömiä lapsen ja kastematojen multaisten seikkailujen yksityiskohdista. On myöhäinen elokuu ja pieni lappilainen kyläkahvila on auki kymmeneen asti illalla - joskus myöhempäänkin, jos jutun juurta riittää kahvilatoimintaa pyörittävien kyläläisten ja asiakkaiden välillä.

Pirpolassa elämä on muutaman vuoden ajan perustunut ajatukseen "tässä on hyvä". Kahdeksan vuotta sitten kylää kosketti rajulla kädellä virusepidemia, joka pakotti matkailutoiminnan muutokseen. Kylän suosio matkailukohteena oli kasvanut noin viiden vuoden ajan, ja kansainväliset matkanjärjestäjät toivat paikalle aasialais- ja brittituristeja tarjoten heille matkailupaketteja. Matkanjärjestäjät hyödynsivät kylän paikallisten matkailuyritysten kansainvälisille matkailijoille räätälöimiä elämyspalveluita. Elettiin kasvun aikaa. Paikallisten matkailuyritysten toiminta ei kuitenkaan ollut ehtinyt kasvaa niin vahvalle pohjalle, että ne olisivat kyenneet selviytymään virusepidemian seurauksista. Matkailijat kaikkosivat. Moni yrittäjä sulki ovensa ja muutti kaupunkiin työn perässä. Hetken näytti, että kylä menettää asukkaansa ja erityisesti ne nuoret perheet, jotka olivat tulleet kylään rakentaakseen tulevaisuutta Lapissa. Jotain kuitenkin tapahtui tuona kahdeksan vuoden takaisena kesänä.

Uusi tilanne antoi kyläyhteisölle mahdollisuuden pohtia kriittisesti aiempia kasvuun nojaavia liiketoimintamalleja. "Jos virusepidemia saapuisi uudelleen, menettäisimmekö jälleen suuren osan yhteisömme jäsenistä liiketoiminnan tyrehtyessä?" "Onko tämä kestävä tapa toimia?" Näin kysyttiin tuolloin elokuun pimenevänä iltana nuotiotulen äärellä, kun kyläläiset kokoontuivat yhteen miettimään tulevaa. Kävi ilmi, että kyläläisiä oli myös mietityttänyt kasvava kansainvälisten pakettimatkaturistien määrä. Turistien määrän lisääntyessä haasteita oli ilmennyt ohjelmapalveluiden tarjoajien, kyläläisille tärkeän kahvila- ja pubitoiminnan ylläpitäjien, kylän 
eläin-, kasvi- ja puuasukkaiden sekä erityisesti aasialaisturistien välisessä kommunikaatiossa ja yhteiselon muotojen löytämisessä.

Kylän metsä oli nähnyt elämää paljon pidempään kuin useampi ihmissukupolvi yhteensä. Metsä oli viisaudessaan ihmisymmärryksen ulottumattomissa mutta samaan aikaan haavoittuva ihmiskunnan toimille. Loppukesän marjastusaikana mustikoiden ja puolukoiden varvut viestivät, että marjoja olivat poimineet ihmiset, joita varvut eivät tunteneet - poimureita oli käytetty varomattomasti ja raakoja marjoja oli poimittu, jolloin suuri osa marjasadosta oli jäänyt käyttökelvottomaksi. Taipuneet ja katkeilleet puunoksat liejuisten luontopolkujen varrella kertoivat tarinaa matkailijoiden määrän ja luontoreitistöjen ylläpidon yhteensopimattomuudesta. Vuosisatoja vanhat, sinnikkään hitaassa rytmissä kasvaneet kiviä peittävät jäkälät olivat repeytyneet ihmisten painavien askelten jäljiltä. Lumi ja jää yllättivät kansainväliset matkailijat vuosi toisensa jälkeen aiheuttaen talviolosuhteisiin tottumattomille kaatumisia, paleltumisia ja eksymisiä sekä kuormittaen pienen kylän pelastustoiminnan resursseja ja demonisoiden "Lapin julmaa luontoa".

Matkailijamäärien lisäännyttyä, yhteisen kielen usein puuttuessa ja kulttuurien ollessa hyvin erilaisia kyläyhteisö oli tullut tilanteeseen, jossa sen oli vaikea toimia omia perinteitään kunnioittaen. Sen oli vaikea välittää vierailijoille kylän historiaa, elämäntapaa sekä metsän, maan ja ilman asukkaita kunnioittavat toimintatavat, joita myös matkailijoiden odotettiin noudattavan. Lisähaasteen yhteisen ymmärryksen syntymiselle aiheutti se, että matkailijat viipyivät kylässä yleensä vain kolme päivää. Moni asia tuli väistämättä virusepidemian takia uudelleenpohdituksi.

Kyläyhteisö alkoi hiljalleen rakentaa perustaa yhteisölliselle elämälle. Siinä keskeistä ei ollut menetettyjen matkailijoiden takaisinhamuaminen eikä "takaisin kasvun tielle" -ideologia vaan kylän ja kyläyhteisön merkityksen uudelleenpohtiminen. Kylän ihmisten elämä oli aina kytkeytynyt tiiviisti vanhan metsän moninaiseen asukaskuntaan, jonka kanssa kylän ihmiset asuttivat maata. Vanha metsä oli kyläläisille jokapäiväisen elon, arvostuksen ja kunnioituksen paikka. Metsässä elämä oli rikasta ja täynnä yllätyksiä, paikkoja, joihin asukkaat hakeutuivat yhä uudelleen. Ihminen aisti vanhan metsän läsnäolossa paikkansa maailmassa osana luontoa. Vanhassa metsässä uudet ihmissukupolvet oppivat, että elämä on ihmisen ja luonnon muiden toimijoiden yhteinen lahja.

Alueella ei ollut koskaan harjoitettu metsätaloutta, ja esimerkiksi rakennettaessa kahvilaa, josta sittemmin oli tullut kylän symboli, puiden kaataminen pyrittiin minimoimaan. Puut loivat kahvilan hämyisän tunnelman, mutta se ei ollut tavoitteellista; puiden läsnäolo oli puhtaasti puiden läsnäoloa, ja hämyisyys syntyi tästä läsnäolosta. Kyläläiset ymmärsivät, että täällä heillä oli mahdollisuus aidosti elää kosketuksessa heitä, meitä, kaikkia yhdistävään luontoon. He halusivat tarjota tämän mahdollisuuden myös muille - "kyläilijöille" - mutta tavoitteellisuuden sijaan he päättivät, että tämä mahdollisuus saisi tulla luonnostaan.

Kyläyhteisö päätti luopua perinteisesti ymmärretystä matkailusta. Kylä haluttiin kyllä pitää jatkossakin avoimena kansainvälisille vieraille - miksi sulkea yhteisö muulta maailmalta? Mutta kylässä toimivia elinkeinonharjoittajia ei enää motivoinut ensisijaisesti usko kansainvälisten matkailijoiden tuomaan taloudelliseen voittoon. Kyläläiset alkoivat panostaa toimiin, jotka takaisivat hyvän elämän kyläläisille ja kyläilijöille osana luontoa läpi vuoden. Matkailusta alettiin 
toden totta puhua kyläilynä, ja vierailijat tukivat kyläyhteisön kasvavaa omavaraisuutta saaden muun muassa nauttia kylän viljelysten annista. Matkailutoimijoista tuli monialaisia toimijoita. Kylässä alettiin panostaa taiteen ja kulttuurin erilaisiin kokeileviin muotoihin, jotka synnyttivät ihmisen luontosuhdetta hoivaavia käytäntöjä. Rikastuva taiteen ja kulttuurin kenttä mahdollisti kyläläisille itsensä sivistämisen ja kehittämisen yhdessä kyläilijöiden kanssa. Yhteisöllisen toiminnan seurauksena syntyi myös kilpailusta vapaa tilanne: jokainen toteutti itselleen luontevinta tapaa olla osa yhteisöä, ja vaihdantaan perustuvan toiminnan ensisijainen motiivi oli aito halu antaa saatu lahja eteenpäin jossain toisessa muodossa. Kapitalistisen neoliberaalin järjestelmän mukaiselle kilpailuasetelmalle ei tällöin yksinkertaisesti ollut tilausta.

Ihmisasukkaat elivät todeksi metsän asukkailta saamiaan oppeja: eri elinkeinot elivät vuodenkierrossa kuunnellen luonnon rytmiä entistä herkemmin. Talven tullen kylään ei kaivattukaan enää vilkasta sesonkia, vaan talvesta tuli jälleen rauhoittumisen aikaa. Kun puut, karhut, kasvit ja monet pienet metsän eläimet nukkuivat talviunta, oli ihmisenkin hyvä hidastaa tahtiaan. Jos kylään tuli talvella vieraita, heillekin tarjottiin mahdollisuus rauhoittumiseen. Kyläläiset viettivät aikaa paljon yhdessä vahvistaen keskinäisiä suhteitaan. He kulkivat hiihtäen metsissä tervehtien uinuvia metsän asukkeja - puita, marjoja, kasveja. Keväällä talviuniltaan heräävä vanha metsä ja sen asukkaat kutsuivat asukkaat ja kyläilijät luokseen.

Kyläyhteisö alkoi elää tarinoina, jotka syntyivät muun muassa puiden, lintujen, ihmisten, mehiläisten, kivien ja mäkäröiden yhteiselon hetkistä. Kylä ei ollut irrallinen muusta maailmasta, vaikka kyläläiset haaveilivatkin yhä vähemmän elämästä ja kokemuksista "jossain muualla". Kylästä alkoi muodostua osavuotinen koti kyläilijöille, jotka tekivät perheinensä töitä tietotekniikan ja hyvien internetyhteyksien mahdollistamana. Monista kyläilijöistä tuli synnyinkyläläisten ystäviä ja pitkäaikaisia yhteisön jäseniä. Heidän jalanjäljissään tuli taas uusia kävijöitä, jotka tiesivät jo saapuessaan paljon kyläyhteisön elämäntavasta ja -filosofiasta. Moni kyläläinenkin alkoi hankkia ihmisen perustarpeet tyydyttävän elantonsa yhdistämällä innovatiivisesti kyläyhteisön omavaraisuuteen perustuvaa paikallista työtä ja tietotekniikan mahdollistamaa etätyöskentelyä. Paikallis- ja globaalitalouden terveellä yhdistelmällä työ alkoi jälleen palvella yksilöiden ja perheiden hyvinvointia, ja tärkeäksi tuli ihmisen ylittävä käsitys hyvinvoinnista. Näin muotoutunut tapa ymmärtää työ ja kyläileminen auttoi kyläyhteisöä palaamaan osaksi luontoa.

Rikkaus muutti muotoaan: kapitaalisesta rikkaudesta siirryttiin hengelliseen, kokemukselliseen rikkauteen, jossa yhteys luontoon oli kaiken keskiössä. Tämän myötä perinteiset mittarit romuttuivat, samoin elinkeinotoiminnan päämäärät. Kyläilijöiden määrän sijaan alettiin tarkastella kyläilykokemusten merkityksellisyyttä. Kun vierailu lähestyi loppuaan, kyläilijöiltä kysyttiin, mitä sellaista he kokivat kyläläisten kanssa, minkä he voivat viedä kotiin, uudelle sukupolvelle, ystäville tai perheelle, perintönä? Mitä yhteiset hetket vanhan metsän kanssa opettivat tai antoivat heille henkisesti? Mitä käytännön tekoja he voisivat toteuttaa kotipaikkakunnallaan, jotta elämästä tulisi kestävämpää ja yhteys luontoon vahvistuisi? "Oletteko tulossa joskus vielä takaisin - jäämme kaipaamaan teitä"! Kylässä vierailleisiin ihmisiin haluttiin pitää yhteyttä kohtaamisen jälkeenkin. Osoitteita vaihdettiin ja postikortteja lähetettiin. Matkailusta muodostui lopulta hoivaava elämäntapa. Kyläläisten elämästä tuli jatkuvaa uuden oppimista osana 
luontoa, yhdessä kyläilijöiden kanssa. Matkailusta tuli sukupolvet yhdistävää, pienistä lapsuuden ensiaskelista ponnistavaa kollektiivista elämää osana luontoa.

\section{Epävarmuudella maustettu konkluusio}

Matkailun uudelleenarviointi ja -rakentaminen vaatii koheesioiden vinouttamista. Se vaatii myös spekulatiivista otetta, perverssiäkin lähestymistä, matkailun ideologioihin. Tämä ei ole, eikä sen kuulukaan olla, helppoa. On epävarmaa, ovatko vaihtoehtoiset matkailun todellisuudet ylipäätään mahdollisia ja onko niiden pohdinnalle sijaa tutkimuskentällämme, saati matkailualan praktisissa käytännössä. Epävarmuudessa meidän täytyy silti pysyä sinnikkäästi vaikeiden kysymysten äärellä.

Aloitin SF-puheenvuoroni kysymällä, onko post-traumaattinen maailma yhtä kuin post-antroposentrinen, ja tarjoaako covid-19-viruspandemien jälkeinen post-traumaattinen maailma mahdollisuuden rakentaa ihmisestä laajentuvaa käsitystä matkailusta. Vastaukseni lienee myönteinen, mutta avautuminen tälle mahdollisuudelle vaatii "mielenkumousta" - lukkiutuneiden ajattelutapojen kyseenalaistamista ja muuttamista (Joutsenvirta ym., 2016). Post-antroposentrisessä maailmassa keskeistä on uteliaisuus sille, mikä voi näyttäytyä ja tulla tietoisuuteemme hyvinkin lähellä, odottamatta.

Spekulatiivinen tarinani tulevaisuuden matkailusta lappilaisessa kylässä rakensi matkailusta kyläilemistä. Kyläileminen perustui yhdessä tekemiselle ja ihmisyyden tunnistamiselle (vain ja jälleen) osana luontoa. Tarinassa ihmisen ylittävän kyläyhteisön vanha metsä asukkaineen oli mukana muovaamassa eettistä toimintaa sen sijaan, että "luonto" tai "metsä" olisi vain instrumentaalinen, passiivinen objekti ihmisen hyveelliselle huomiolle (Hawkins, 2018, s. 19) - saati pelkkä ihailun kohde tai uusien kokemusten lähde. Kun matkailusta muotoutui tarinassa ihmisen ylittävää, hoivaavaa kyläilyä, siinä tarjottiin myös uusia vaihtoehtoisia työvoimapoliittisia tulevaisuuksia. Uudenlaisia näkökulmia tarjottiin myös niihin argumentteihin, joilla matkailun - sellaisena kuin sen nyt tunnemme - motiiveja ja hyväksyttävyyttä perustellaan.

Matkailun vaihtoehtoinen tarina kulkee käsi kädessä laajempien, talouskasvun vaihtoehtoisten tarinoiden kanssa. Epävarmuuden ajat, koronaviruksen tuomat seuraukset ja yllättävät vaikutukset yhdessä työmarkkinoiden epävakauden kanssa kannustavat meitä rahallisten ja ei-rahallisten toimeentulovirtojen monipuolistamiseen (Joutsenvirta ym., 2016, luku 5). Ehdottamani hoivaava kyläily on osa laajasti ymmärrettävää taloutta, jonka olennaisia osia ovat kollektiivinen tekeminen ja oman ajankäytön itsemääräämisoikeus (Joutsenvirta ym., 2016).

Post-antroposentriset matkailun maailmat edellyttävät yhteiskunnallista muutosta, joka tapahtuu yhden ulottuvuuden sijaan monella eri tasolla. Joutsenvirta ym. (2016) muistuttavatkin yhteiskunnallisen muutoksen monitasoisuudesta. Tämä monitasoisuuden tunnistaminen rakentaa pohjaa matkalle tästä SF-puheenvuorostani eteenpäin. Matka lähtee liikkeelle useista vastausta vailla olevista kysymyksistä. Millaisia ovat tai voisivat olla hoivaavat suhteet matkailupoliittisten päätösten tekemisessä? Entä hoivaavat suhteet matkailun institutionaalisten rakenteiden muokkaamisessa? Tai hoivaavat suhteet tulevaisuuden matkailijoiden tai kyläilijöiden 
arkipäiväisen toiminnan, työnteon ja ajattelutapojen muuttamisessa? Millaisia ovat ei-inhimillisen maailman hoivaavat suhteet, jotka voivat uudelleenjärjestää myös ihmislajin toimintaa?

Tarinani on fiktiivinen, eikä siihen sisälly paljoakaan tarinassa kuvattuun elämäntapaan sisältyviä haasteita ja ongelmakohtia. Se on kuitenkin paikka, josta voimme lähteä avaamaan ajatuslukkoamme. Muistammehan, että spekulatiivinen fabulaatio on armeliasta - se on "yhä mahdollisten" tulevaisuuksien kuvittelemista sinnikkäästi (Haraway, 2016). Tähän sisältyy toiveen ja uskon siemen: ei ole vielä myöhäistä aikaansaada muutosta. Mahdollisten maailmojen ja aikojen kuvittelu ei ole kuitenkaan pelkkää ajatusleikkiä - se on kuviointia, kirjomista, hahmottamista (Haraway, 2016, s. 31). Tämä kirjominen vaatii uteliaisuutta ja, jälleen Harawayn (2016, s. 126-133) sanoja lainaten, uteliaita käytäntöjä. Tämä on vastuunottoa, toimimista vastuunottoon kykenevänä.

Loppujen lopuksi matkailu postpandemisessa maailmassa on ehkä Karen Baradin (2007) ajatuksia seuraten maailmankaikkeuden kohtaamista puolitiessä: "Meeting the universe halfway". Ehkä ei ole niin tärkeää, mikä on tuo tarkka puoliväli, vaan sen filosofinen ajatus: meidän täytyy avautua epävarmuudelle ja epäkonventionaisuudelle voidaksemme elää (kestävästi) luonnon eri kompleksisten toimijuuksien kanssa ja oppien kohtaamisistamme. Tarvitsemme myös toisiamme - ihmisinä - käydäksemme keskustelua siitä, mitä me geopoliittisina voimina voimme tehdä suunnataksemme voimamme johonkin sellaiseen, mikä hyödyntämisen sijaan hoivaa yhteistä planeettaamme. Puolivälissä kohtaaminen tarkoittaa myös antamista, pyyteettömyyttä, eikä vain sen odottamista, että meille annetaan kyllä myös takaisin. Luonnon toimijat, kuten virus, jolle olemme antaneet nimen covid-19, jatkavat ihmiskunnan koettelemista myös tulevaisuudessa, vaikka ymmärtäisimmekin paremmin hoivaavien suhteiden merkityksen planeettamme tulevaisuuden kannalta. Mutta ehkä voimme paremmin löytää ratkaisuja yhteiseen elämäämme niiden kanssa. Epävarmuudessa ja epätietoudessa pyyteettömyys voikin toteutua - emmehän silloin edes tiedä, mitä odottaa, joten miten voisimme odottaa?

$$
* * *
$$

Tämä puheenvuoro on tuotettu osana Suomen Akatemian rahoittamaa Lapin yliopiston tutkimusprojektia Matkailua lähelle - uusmaterialistinen näkökulma (324493, www.ilarctic.com).

\section{Lähteet}

Alaruona, A. (2018). Nämä maailmat ovat jo - Kirjoittaminen queer-feministisenä maailman tekemisenä. Opinnäytetyö, Taideyliopiston Teatterikorkeakoulu.

Barad, K. (2003). Posthumanist performativity: Toward an understanding of how matter comes to matter. Signs, 28(3), 801-831. https://doi.org/10.1086/345321

Barad, K. (2007). Meeting the universe halfway: Quantum physics and the entanglement of matter and meaning. Durham.

Berge, C. (2020) How can we be sustainable post-Covid 19? BBC Travel, 16th April, 2020. http:// www.bbc.com/travel/story/20200415-how-can-we-be-sustainable-post-covid-19 
Bjurström, E. \& Virtanen, J. (2019). Järkyttävä näky kohtasi vaeltajia keskellä Lapin erämaata: Jätteitä pitkin luontoa, ylipursuavia roskiksia ja tyhjiä kalja- ja viinapulloja. YLE uutiset. 21.9.2019. https://yle.fi/uutiset/3-10982461

Eijgelaar, E., Amelung, B. \& Peeters, P. (2016). Keeping tourism's future within a climatically safe operating space. Teoksessa M. Gren \& E. B. Huijbens (toim.), Tourism and the Anthropocene (s. 17-33). Routledge.

Eisenstein, C. (n.d.). Short course: Unlearning for change agents. https://charleseisenstein.org/ courses/unlearning-for-change-agents/

Fisher, B. \& Tronto, J. (1990). Towards a feminist theory of caring. Teoksessa E. K. Abel \& M. K. Nelson (toim.), Circles of care: Work and identity in women's lives (s. 35-62). State University of New York Press.

Gren, M. \& Huijbens, E. B. (2016). Tourism and the Anthropocene. Routledge.

Grimwood, B., Caton, K. \& Cooke, L. (2018). New moral natures in tourism. Routledge.

Haraway, D. (2008). When species meet. University of Minnesota Press.

Haraway, D. (2016). Staying with the trouble: Making kin in the Chthulucene. Duke University Press.

Hawkins, G. (2018) Ethical blindness: Plastics, disposability and the art of not caring. Teoksessa V. Kinnunen \& A. Valtonen (toim.), Living ethics in a more-than-human world (s. 15-27).

Huijbens, E. (2020). 3 ways to transform tourism to fight climate change. TEDx talk, Wageningen University, 30.10.2020. https://www.youtube.com/watch?v=cZ8fw2F_E8Y\&app=desktop

Huijbens, E., Costa, B. M. \& Gugger, H. (2016). Undoing Iceland? The pervasive nature of the urban. Teoksessa M. Gren \& E. B. Huijbens (toim.), Tourism and the Anthropocene (s. 34-51). Routledge.

Huijbens, E. \& Gren, M. (2016) Tourism and the Anthropocene: An urgent emerging encounter. Teoksessa M. Gren E. B. \& Huijbens (toim.), Tourism and the Anthropocene (s. 1-13). Routledge.

Jamal, T. \& Budke, C. (2020). Tourism in a world with pandemics: Local-global responsibility and action. Journal of Tourism Futures. https://doi.org/10.1108/JTF-02-2020-0014

Joutsenvirta, M., Hirvilammi, T., Ulvila, M. \& Wilén, K. (2016). Talous kasvunjälkeen. Gaudeamus Helsinki University Press.

Kinnunen, V. (2017). Tavarat tiellä: Sosiologinen tutkimus esinesuhteista muutossa. (Acta Universitatis Lapponiensis 362.) Lapin yliopisto.

Klein, N. (2014). This changes everything: Capitalism vs. the climate. Simon and Schuster.

Kortekallio, K., Niskavaara, M., Ouramo, H., Raipola, J., Salmela, T., Tervonen, A. \& Karhulehto, S. (tulossa). Ehdotus ihmistä suhteellistavaksi sanastoksi. Avain, 4/20, teemanumero Metsä.

Koskinen, O., Mattila, M., Mesiranta, N. \& Närvänen, E. (2018). Hoiva ruokahävikin vähentämisen arkisissa käytännöissä. Alue \&Ympäristö, 47(2), 17-31.

Mehtonen, J. \& Heikinmatti, A. (2019). Roskaa ja tölkkejä kansallispuistossa, kivikasoja tunturissa - kestääkö Lappi massaturismia, vai ovatko edessä Balin ja Islannin ongelmat? YLE uutiset 4.10.2019. https://yle.fi/uutiset/3-10997630 
Palsson, G. \& Swanson, H. A. (2016). Down to Earth - Geosocialities and geopolitics. Environmental Humanities, 8(2), 149-171. https://doi.org/10.1215/22011919-3664202

Prideaux, B., Thompson, M. \& Pabel, A. (2020). Lessons from COVID-19 can prepare global tourism for the economic transformation needed to combat climate change. Tourism Geographies, 22(3), 667-678. https://doi.org/10.1080/14616688.2020.1762117

Puig de la Bellacasa, M. (2017). Matters of care: Speculative ethics in more than human worlds. University of Minnesota Press.

Romagosa, R. (2020). The COVID-19 crisis: Opportunities for sustainable and proximity tourism, Tourism Geographies, 22(3), 690-694. https://doi.org/10.1080/14616688.2020.1763447

Tsing, A. (2015). The mushroom at the end of the world: On the possibility of life in capitalist ruins. Princeton University Press.

Vetlesen, A. J. (2019). Cosmologies of the Anthropocene: Panpsychism, animism, and the limits of posthumanism. Routledge.

YLE (2019). Hyvä-paha turismi: mitkä ovat Lapin matkailun kasvun rajat? (27.11.2019 klo 11.30).

Katsottavissa 26.11.2020 asti Yle Areenassa: https://areena.yle.fi/1-50360706 